\title{
Pengaruh Kepemimpinan Transformasional, Kompensasi Dan Good Corporate Governance Terhadap Kinerja Karyawan
}

\author{
Redi Yuniansyah Elyanto ${ }^{1 *}$, Bambang Syairudin ${ }^{2}$ \\ ${ }^{1,2}$ Manajemen Industri MMT ITS Surabaya, Indonesia \\ ${ }^{1}$ rediyuniansyah88@gmail.com, ${ }^{2}$ bambangsyairudin@gmail.com
}

\begin{abstract}
ABSTRAK
Penelitian ini bertujuan untuk menganalisa bagaimana pengaruh kepemimpinan transformasional, kompensasi dan Good Corporate Governance terhadap kinerja karyawan. Populasi dalam sampel ini adalah seluruh karyawan dari beberapa perusahaan yang bergerak di bidang jasa survey kepelabuhanan dan penilai kerugian asuransi. Sebuah kuesioner di desain sebagai metode pengumpulan data dari seluruh populasi atau sampel yang dalam penelitian ini. Kemudian setelah data tersebut diperoleh,akan dianalisa dengan menggunakan metode Partial Least Square $(P L S)$.Penelitian ini menunjukkan bahwa ketiga variabel yaitu kepemimpinan transformasional, kompensasi serta good corporate governance berpengaruh positif terhadap kinerja karyawan, namun hanya variabel good corporate governance yang berpengaruh signifikan terhadap kinerja karyawan.
\end{abstract}

Kata Kunci: Kepemimpinan Transformasional, Kompensasi, Good Corporate Governance, Kinerja Karyawan

\begin{abstract}
This research aim to analyze the influence of transformational leadership, compensation, and Good Corporate Governance towards employee performances. The population of this research is all of the employee fromsome companies which work in Indonesia which work in the field of marine supervision survey and loss adjusting of the insurance company. A questionaire designed to collect the data from all of the population or samples of this research. Then when the data already collected, the data will be examine and analyze by using Partial Least Square (PLS) method. The research results shown that the three factors of transformational leadership, compensation and good corporate governance give a positive influence to the employee performance, however only the variabel good corporate governance which give a significant influence for the employee performance.
\end{abstract}

Keywords: Transformational Leadership, Compensation, Good Corporate Governance, Employee Performance 


\section{PENDAHULUAN}

Perkembangan industri asuransi dan kemaritiman di Indonesia saat ini telah berkembang dengan pesat, terutama pertumbuhan perusahaan yang bergerak di bidang pelayanan jasa penilai kerugian (Loss Adjuster) dan supervisi kegiatan kepelabuhanan, kemaritiman \& manajemen resiko (Marine Surveyor). Menurut Otoritas Jasa Keuangan (OJK) Republik Indonesia, hingga saat ini terdapat 27 perusahaan penilai kerugian (Loss Adjuster) baik yang bergerak di bidang marine, non marine dan motor vehicle beroperasi di seluruh wilayah Indonesia. Sedangkan untuk perusahaan yang melaksanakan unit usaha di bidang marine surveyor, terdapat lebih dari 100 perusahaan yang beroperasi di Indonesia.Keseluruhan perusahaan Loss Adjusting dan Marine Surveyor tersebut merupakan perusahaan berkepemilikan pemerintah, swasta lokal dan perusahaan bermodalkan atau perwakilan dari perusahaan asing.

Di sisi lain, Industri Asuransi di Indonesia masih membutuhkan lebih banyak tenaga tim penilai kerugian (Adjuster) yang memiliki kemampuan dan daya saing yang baik, karena dalam beberapa tahun ke depan diperkirakan industri asuransi di Indonesia akan berkembang dengan pesat seiring dengan meningkatnya kesadaran masyarakat terhadap asuransi, terutama asuransi umum atau asuransi kerugian. Dengan perkembangan tersebut, tentunya usaha di bidang Loss Adjuster dan Marine Surveyor akan mengikuti perkembangan tersebut secara linier. Dampak yang paling terasa dari pertumbuhan dan perkembangan perusahaan Loss Adjusting dan Marine Surveyor tersebut bagi setiap perusahaan adalah semakin ketat dan komplek persaingan untuk memperoleh serta mempertahankan pangsa pasar yang dimiliki.

Sebagai contoh kasus, PT. NKKK Indonesia sebagai salah satu perusahaan yang beroperasi di Indonesia sebagai loss adjuster dan marine surveyor, tentu akan menghadapi kompleksitas persaingan di Indonesia. Persaingan ini akan berpengaruh dan memberikan dampak terhadap produktifitas dan eksistensi perusahaan tersebut dalam persaingan industry loss adjuster dan marine surveyor di Indonesia. Sebagai akibat dari persaingan tersebut, selama kurun waktu 5 tahun terakhir ini PT. NKKK Indonesia cenderung mengalami penurunan jumlah penunjukkan atau permintaan jasa survey dari pelanggan sebesar 34\% hingga akhir tahun 2015, namun demikian rataan penanganan kasus per karyawan tidak mengalami penurunan secara signifikan. Sehingga kondisi ini berdampak secara langsung pada penurunan pendapatan bersih perusahaan selama kurun waktu 5 tahun terakhir.

Penurunan produktifitas perusahaan ini seharusnya juga dihadapi oleh beberapa perusahaan dan penurunan ini diduga merupakan efek yang ditimbulkan dari ketidakmampuan karyawan untuk menyeimbangkan, menjaga serta meningkatkan kualitas kinerja. Disamping itu peran dan pengaruh dari kepemimpinan yang dimiliki oleh seorang pimpinan perusahaan juga akan mempengaruhi kinerja perusahaan dan karyawan. Sehingga perusahaan perlu melakukan evaluasi dan perbaikan kinerja dikarenakan mesin utama dari sebuah organisasi atau perusahaan adalah SDM dengan segala kemampuan dan keterampilan yang dimiliki (Lendzion, 2015).

Pusat operasional perusahaan berada pada kinerja dari masing-masing karyawan didalamnya. Jika mempertimbangkan kondisi peta persaingan yang semakin ketat dengan tanpa diimbangi dengan perubahan atau peningkatan kualitas sumber daya manusia dalam perusahaan tersebut, maka akan sangat sulit bagi masing-masing perusahaan untuk memperbaiki posisi dan mempertahankan eksistensi perusahaan di persaingan pasar loss adjusting dan marine surveyor di Indonesia.

Sehingga Perusahaan harus segera merubah paradigma bisnis mereka menjadi 
lebih modern dimana pusat kegiatan sebuah perusahaan atau organisasi adalah karyawan/ orang-orang yang berada di dalamnya. Sebuah perusahaan harus segera direvitalisasi sebelum permasalahan lanjutan akan muncul (Guidelines for Early Revitalization of Business, 2003). Adapun secara garis besar perubahan dan perbaikan ini sendiri tujuannya adalah peningkatan kinerja karyawan secara berkesinambungan dan seimbang dalam jangka panjang.

Dalam usahanya untuk meningkatkan kinerja, sebuah organisasi/ perusahaan diwajibkan untuk mengetahui faktor-faktor yang dapat mempengaruhi kinerja itu sendiri untuk memperoleh manfaat dari pengelolaan sumber daya manusia secara komprehensif. Dan seorang pimpinan perusahaan harus mulai sadar dan paham akan hal tersebut karena sebuah perusahaan tidak akan bertahan cukup lama jika ada pemikiran secara serius/ vital akan hal tersebut (Ciolacu, 2012).

Salah satu faktor penting sebagai kunci keberhasilan pengelolalaan sumber daya manusia tersebut adalah bagaimana kualitas kepemimpinan yang dimiliki oleh seorang pemimpin perusahaan.Salah satu tipe kepemimpinan yang berkembang saat ini adalah kepimpinan transformasional. Dimana menurut Yildiz et.al. (2014), kepemimpinan transformasional adalah suatu keadaan dimana seorang pemimpin mempunyai sebuah karisma serta visi ke depan yang sangat jelas dan terarah, sehingga mampu mentransformasikan seluruh anggota maupun karyawan dan menjadi lebih terinspirasi, percaya dan yakin akan kepentingan masing-masing dalam pekerjaannya demi mewujudkan tujuan bersama.

Disamping faktor kepemimpinan, sebuah perusahaan juga harus memberikan perhatian lebih mengenai hak masing-masing karyawan yaitu pemberian kompensasi. Merujuk pada penelitian Hameed (2014) menunjukkan bahwa pemberian kompensasi (gaji/ upah, penghargaan, dan kompensasi tidak langsung) memberikan dampak positif pada kinerja karyawan.

Lebih lanjut menurut penelitian Mondiani (2012), menunjukkan bahwa tipe kepemimpinan transformasional dan kompensasi ini memberikan dampak yang signifikan terhadap kinerja karyawan.

Adapun upaya penilaian maupun perbaikan kinerja karyawan ini sebaiknya berlandaskan pada prinsip - prinsip tata kelola perusahaan yang baik (Good Corporate Governance). Menurut Brandas (2015), penerapan tata kelola perusahaan (corporate governance) dalam sebuah perusahaan sangat penting sebagai salah satu proses dan tools untuk menjaga serta meningkatkan kinerja dan eksistensi sebuah perusahaan dalam jangka waktu panjang yang lebih mengutamakan kepentingan para pemangku kepentingan (stakeholder) dan pemegang saham (shareholder). Kemudian merujuk pada penelitian sebelumnya yang dilaksanakan oleh Handoko (2015) dan Jayanti et. al. (2016) menunjukkan bahwa penerapan prinsip GCG (Accountability, Fairness, Independency, Responsibility, dan Transparancy) mampu memberikan pengaruh positif terhadap kinerja karyawan.

Berdasarkan latar belakang penelitian yang telah dijelaskan dan merujuk pada penelitian yang telah dilaksanakan oleh Ghafoor (2011), Mondiani (2012), Yildiz et. al. (2014), dan Guiu et. al. (2016); maka rumusan masalah yang akan coba dijawab melalui penelitian ini adalah sebagai berikut:

a. Apakah kepemimpinan transformasional berpengaruh terhadap kinerja karyawan?

b. Apakah kompensasi yang diberikan berpengaruh terhadap kinerja karyawan?

c. Apakah keberadaan prinsip tata kelola perusahaan yang baik (GCG) berpengaruh terhadap kinerja karyawan? 


\section{KAJIAN PUSTAKA}

\section{Kepemimpinan Transformasional}

Menurut Ivancevich, Konopaske dan Matteson (2006), pemimpin transformasional adalah pemimpin yang mampu memotivasi para pengikutnya untuk dapat bekerja mencapai sebuah tujuan tertentu, bukan demi kepentingan pribadi atau individu jangka pendek, serta untuk dapat memenuhi suatu prestasi kerja dan aktualisasi diri sendiri. Kemudian menurut Gibson et.al.(2006), kepemimpinan transformasional adalah sebuah kemampuan untuk menginspirasi dan memotivasi pengikutnya untuk mendapatkan hasil yang lebih baik dari tujuan semula dan untuk penghargaan internal.Disamping itu, Robbins dan Judge (2015) menyatakan tipe kepemimpinan transformasional adalah sebuah tipe kepemimpinan yang dimiliki oleh seorang pemimpin yang mampu menginspirasi para pengikutnya untuk dapat melampaui kepentingan diri mereka sendiri dan yang berkemampuan untuk memiliki pengaruh secara mendalam dan luar biasa terhadap para pengikutnya.

Menurut Robbins dan Judge (2015), ciri-ciri kepemimpinan transformasional yang mampu memacu inovasi serta kreatifitas dalam organisasi adalah sebagai berikut:

1. Pengaruh Yang Ideal (Idealized Influence), aspek ini meliputi: pemberian visi dan misi yang jelas, menanamkan sifat dan rasa kebanggaan, serta mendapatkan respek dan kepercayaan.

2. Motivasi Inspirasional (Inspirational Motivation), Aspek ini meliputi: kemampuan untuk mengkomunikasikan ekspektasi tinggi, menggunakan pernyataan-pernyataan yang berfokuskan pada upaya serta menyatakan tujuantujuan yang penting secara lebih sederhana.

3. Stimulasi Intelektual (Intellectual Stimulation), Aspek ini meliputi: berfokus pada peningkatan kecerdasan, rasionalitas dan metode penyelesaian masalah yang cermat dari pengikutnya.

4. Keramahan/ Pertimbangan Individu (Individual Consideration), Aspek dalam hal ini adalah: memberikan perhatian secara pribadi, memberikan pelatihan dan saran serta mampu memperlakukan masing-masing karyawan secara individual.

Menurut Gibson et.al. (2006), perkembangan faktor-faktor yang membentuk kepemimpinan transformasional adalah merujuk pada hasil penelitian yang dilakukan oleh Bass (1985), yaitu antara lain:

1. Karisma (Charisma), Pemimpin harus mampu menanamkan rasa nilai, rasa hormat dan kebanggan serta mengartikulasikan visi.

2. Perhatian Indiviu (Individual Attention), Pemimpin memberikan perhatian lebih kepada masing-masing individu dan memberikan tugas pada proyek yang bermakna sehingga pengikut akan tumbuh secara pribadi.

3. Stimulasi Intelektual (Intellectual Stimulation), Pemimpin membantu pengikutnya untuk berpikir secara rasional dalam mempelajari situasi. Dia mendorong pengikutnya untuk menjadi kreatif.

4. Penghargaan Kontingen (Contingent Reward), Pemimpin menginformasikan kepada pengikutnya mengenai apa yang harus diselesaikan untuk mendapatkan penghargaan.

5. Manajemen Dengan Pengecualian (Management by Exception), Pemimpin memberikan ijin kepada pengikutnya untuk mengerjakan tugasnya dengan tidak memberikan tekanan atau intervensi kecuali jika pengikut tersebut tidak mampu mencapai tujuan pada waktu dan kondisi yang telah ditentukan sebelumnya. 


\section{Kompensasi}

Dessler (2015) menjelaskan bahwa kompensasi adalah merupakan semua bentuk bayaran atau imbalan yang diberikan kepada karyawan dan timbul sebagai akibat dari sebuah hubungan kerja. Dimana dalam kompensasi, seseorang dapat menjumpai beberapa tipe keadilan, yaitu:

1. Keadilan Eksternal, yaitu bagaimana membandingkan tingkat bayaran suatu pekerjaan di sebuah perusahaan dibandingkan dengan tingkat bayaran pekerja sejenis di perusahaan lain.

2. Keadilan Internal, yaitu bagaimana membandingkan sejauh mana tingkat bayaran tersebut adil apabila dibandingkan dengan pekerjaan lain dalam sebuah perusahaan yang sama (misal membandingkan bayaran yang diterima oleh manajer penjualan dengan manajer produksi)

3. Keadilan Individual, yaitu bagaimana membandingkan bayaran masing-masing individu jika dibandingkan dengan yang diperoleh rekan kerjanya atau oleh pekerjaan yang sangat serupa dalam perusahaan tersebut berdasarkan kinerja masing-masing karyawan.

4. Keadilan Prosedural, yaitu merujuk pada "keadilan prosed dan prosedur yang dirasakan yang digunakan untuk mengambil keputusan mengenai alokasi bayaran.

Menurut Hameed (2014), pemberian kompensasi dalam sebuah perusahaan pada umumnya berupa:

a. Gaji/ Upah (Salary)

Menurut Mondiani (2012), pemberian gaji/ upah ini didasarkan beberapa faktor, yaitu;

- Menurut prestasi kerja, semakin besar prestasi karyawan, maka semakin besar pula gaji/ upah yang diterima

- Menurut lamanya pekerjaan, pemberian gaji/ upah dalam hal ini tergantung pada lama karyawan dalam menyelesaikan pekerjaan

- Menurut senioritas, dalam hal ini semakin lama karyawan tersebut bekerja pada suatu perusahaan akan menunjukkan tingkat loyalitas karyawan tersebut, sehingga memberikan pertimbangan tersendiri dalam penentuan gaji/ upah yang akan diterima

- Menurut kebutuhan, penetapan besaran gaji/ upah didasarkan pada tingkat urgensi kebutuhan hidup yang layak dari karyawan tersebut

b. Insentif dan Penghargaan (Incentives and Rewards)

Menurut Hameed (2014), Insentif dan penghargaan memegang peranan penting dalam membentuk kualitas kinerja dari setiap karyawan. Pada umumnya hal ini akan berkaitan langsung terhadap kepuasan karyawan sehingga hal ini akan mendorong masing-masing karyawan untuk lebih kreatif dan lebih bersemangat dalam berkontribusi untuk perusahaan.

c. Kompensasi Tidak Langsung (Indirect Compensations)

Menurut Byars \& Rul (2008) dan Hameed (2014), ada beberapa tipe kompensasi tidak langsung dalam sebuah perusahaan, yaitu:

- Jaminan Sosial (Social Security), seperti asuransi kesehatan.

- Kompensasi karyawan (Workers Compensation), seperti jaminan kesehatan dan pemberian hak istirahat bagi karyawan yang sakit. 
- Dana pensiun (Retirement Plan), seperti pemberian tunjangan/ pendapatan bagi karyawan yang telah memasuki masa pensiun dan berkontribusi dalam sebuah perusahaan.

- Biaya Hari Libur (Paid Holiday), sebagian besar perusahaan akan memberikan tambahan pendapatan karyawan pada saat-saat tertentu seperti tahun baru, hari raya idul fitri, natal dan lain sebagainya.

- Biaya Liburan (Paid for Vacation), sebagian besar perusahaan akan mmberikan kesempatan bagi seluruh karyawannya untuk memperoleh hak berliburan dengan dibiayain oleh perusahaan atau pemberian tambahan pendapatan sebagai pengganti liburan tersebut.

- Manfaat atau kompensasi lain (Other Benefits), seperti kartu kredit, kartu diskon, kendaraan operasional dan lain sebagainya.

\section{Good Corporate Governance (GCG)}

Menurut KNKG (2006), Brandas (2015) dan Jayanti et.al. (2016), Good Corporate Governance (Tata Kelola Perusahaan yang Baik) merupakan prinsip-prinsip yang mengarahkan dan mengendalikan perusahaan agar mencapai keseimbangan antara kekuatan serta kewenangan perusahaan dalam memberikan pertanggung-jawabannya kepada stakeholders.

Adapun prinsip-prinsip GCG menurut pedoman dari Komite Nasional Kebijakan Governance (KNKG, 2006) tersebut antara lain:

a. Transparansi (Transparency), adalah merupakan keterbukaan dalam melaksanakan proses pengambilan keputusan, dan keterbukaan dalam mengemukakan informasi materiil dan relevan mengenai perusahaan.

b. Akuntabilitas (Accountability), dimana perusahaan harus dapat mempertanggung jawabkan kinerjanya secara transparan dan wajar. Untuk itu diperlukan kejelasan fungsi, pelaksanaan dan pertanggung-jawaban organ sehingga pengelolaan perusahaan terlaksana secara efektif.

c. Responsibilitas (Responsibility), sebuah perusahaan harus memiliki kesesuaian dalam pengelolaan perusahaan terhadap perundang-undangan dimana perusahaan dikelola secara profesional tanpa benturan kepentingan dan pengaruh tekanan dari pihak manapun yang tidak sesuai dengan perundang-undangan yang berlaku dan prinsip-prinsip korporasi yang sehat.

d. Independensi (Independency), perusahaan harus dikelola secara profesional tanpa benturan kepentingan dan pengaruh/tekanan dari pihak manapun yang tidak sesuai dengan perundang-undangan yang berlaku dan prinsip-prinsip korporasi yang sehat.

e. Kewajaran dan Kesetaraan (Fairness), sebuah perusahaan harus memegang prinsip keadilan dan kesetaraan dalam memenuhi hak-hak stakeholders yang timbul berdasarkan perjanjian dan peraturan perundang-undangan yang berlaku.

\section{METODOLOGI PENELITIAN}

\section{Diagram Alir Penelitian}

Secara umum, penelitian ini diselesaikan melalui beberapa tahapan, sebagaimana terlihat dalam gambar 1 dibawah ini: 


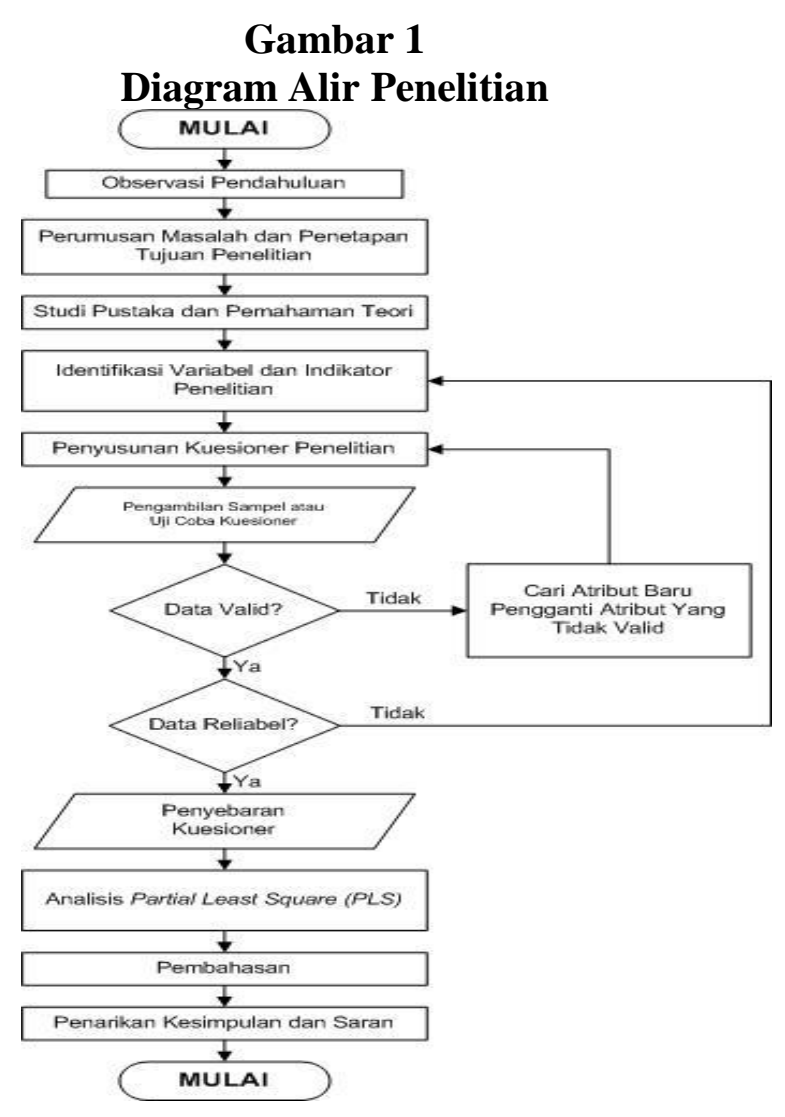

\section{Hipotesis Penelitian}

Dengan mempertimbangkan serta mempelajari beberapa penelitian terdahulu, berikut adalah hipotesis yang akan diajukan oleh peneliti adalah sebagai berikut:

H1 : Kepemimpinan Transformasional berpengaruh signifikan terhadap Kinerja Karyawan

H2 : Kompensasi yang diberikan berpengaruh signifikan terhadap Kinerja Karyawan

H3 : Tata Kelola Perusahaan Yang Baik $(G C G)$ berpengaruh signifikan terhadap kinerja karyawan

\section{Populasi Dan Sampel \\ Populasi}

Populasi merupakan jumlah keseluruhan dari unit analisis yang ciri-cirinya akan diduga. Populasi dari penelitian ini adalah karyawan dari beberapa perusahaan yang bergerak di bidang marine surveyor dan loss adjuster yaitu sebanyak 110 orang.

\section{Sampel}

Sebuah sampel adalah sehimpunan kecil kasus yang dipilih peneliti dari himpunan besar dan akan menggeneralisasi populasi tersebut (Sugiyono, 2013). Oleh karena itu sampel yang diambil dari populasi harus mewakili (representative) keseluruhan populasi.Merujuk pada tabel Nomogram Herry King (Sugiyono, 2013), jumlah sampel yang mewakili populasi dalam penelitian ini adalah 78 orang. 


\section{HASIL PENELITIAN DAN PEMBAHASAN}

\section{Analisa Deskriptif}

Kepemimpinan Transformasional

Dalam Gambar 4.1 dibawah ini menunjukkan bahwa sebanyak 46 responden atau sekitar $58.97 \%$ sudah memahami dan mengerti mengenai apa yang dimaksud dengan Kepemimpinan Transformasional, sedangkan sisanya sekitar 32 responden atau 41.03\% belum familiar dengan istilah Kepemimpinan Transformasional tersebut. Dengan mempertimbangkan bahwa semua indikator Kepemimpinan Transformasional tersebut sangat dekat dengan keseharian responden yang tentunya secara tidak langsung peneliti mengasumsikan bahwa responden tersebut telah mengetahui mengenai Kepemimpinan Transformasional namun belum familiar dengan istilah tersebut, maka peneliti tetap melaksanakan penelitian terhadap keseluruhan sampel/ responden.

Gambar 2

Persentase Jawaban Responden KTR1

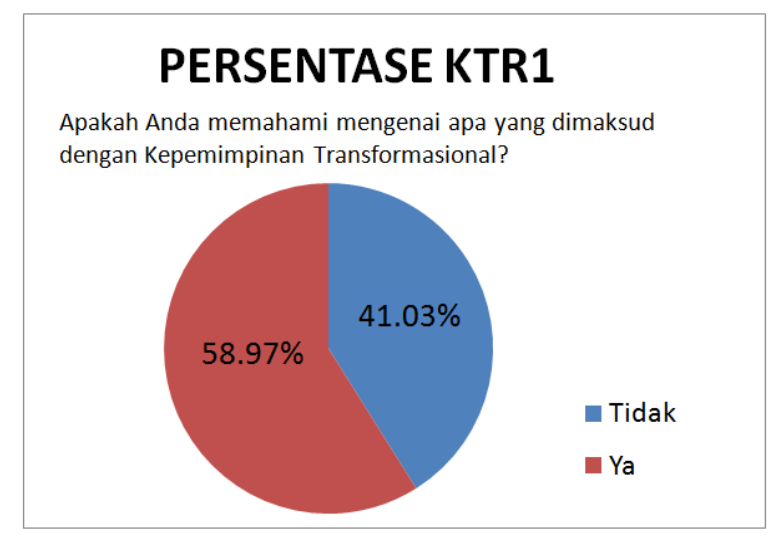

Tabel 1

Rincian Jawaban Untuk Variabel Kepemimpinan Transformasional

\begin{tabular}{|c|c|c|c|c|c|c|}
\hline \multirow{2}{*}{ Indikator } & STS & TS & N & S & SS & \multirow{2}{*}{ Rata - rata } \\
\cline { 2 - 6 } & 1 & 2 & 3 & 4 & 5 & \\
\hline X1.1 & - & 2 & 14 & 77 & 63 & 4.29 \\
\hline X1.2 & - & 3 & 16 & 76 & 61 & 4.25 \\
\hline X1.3 & - & 5 & 13 & 72 & 66 & 4.28 \\
\hline X1.4 & - & - & 23 & 69 & 64 & 4.26 \\
\hline Jumlah & - & 10 & 66 & 294 & 254 & 4.27 \\
\hline
\end{tabular}

Dari Tabel 1 dapat dilihat bahwa rata-rata jawaban yang diberikan oleh para responden untuk masing-masing indikator variabel kepemimpinan transformasional 
adalah sebesar 4.27. Hal ini menunjukkan kepemimpinan transformasional di dalam sebuah perusahaan memegang peranan cukup besar dalam kemajuan perusahaan.

Kompensasi

Tabel 2

Rincian Jawaban Untuk Variabel Kompensasi

\begin{tabular}{|c|c|c|c|c|c|c|}
\hline \multirow{2}{*}{ Indikator } & STS & TS & N & S & SS & Rata - \\
\cline { 2 - 7 } & 1 & 2 & 3 & 4 & 5 & rata \\
\hline X2.1 & - & 2 & 29 & 83 & 42 & 4.06 \\
\hline X2.2 & 2 & 12 & 25 & 75 & 42 & 3.92 \\
\hline X2.3 & 2 & 6 & 31 & 72 & 45 & 3.97 \\
\hline Jumlah & 4 & 20 & 85 & 230 & 129 & 3.98 \\
\hline
\end{tabular}

Dari Tabel 2 dapat dilihat bahwa rata-rata jawaban yang diberikan oleh para responden untuk masing-masing indikator variabel Kompensasi adalah sebesar 3.98. Hal ini menunjukkan pemberian kompensasi di dalam sebuah perusahaan sudah cukup baik, namun perlu ditingkatkan guna memberikan semangat kepada masing-masing karyawan untuk meningkatkan kinerjanya.

Good Corporate Governance

Tabel 3

Rincian Jawaban Untuk Variabel Good Corporate Governance (GCG)

\begin{tabular}{|c|c|c|c|c|c|c|}
\hline \multirow{2}{*}{ Indikator } & STS & TS & $\mathrm{N}$ & $\mathrm{S}$ & $\mathrm{SS}$ & \multirow{2}{*}{ Rata - rata } \\
\cline { 2 - 6 } & 1 & 2 & 3 & 4 & 5 & \\
\hline X3.1 & - & 4 & 18 & 88 & 46 & 4.13 \\
\hline X3.2 & - & 3 & 28 & 78 & 47 & 4.08 \\
\hline X3.3 & 3 & 3 & 28 & 73 & 49 & 4.04 \\
\hline X3.4 & - & 1 & 17 & 80 & 58 & 4.25 \\
\hline X3.5 & - & 4 & 19 & 76 & 57 & 4.19 \\
\hline Jumlah & 3 & 15 & 110 & 385 & 257 & 4.14 \\
\hline
\end{tabular}

Dari Tabel 3 dapat dilihat bahwa rata-rata jawaban yang diberikan oleh para responden untuk masing-masing indikator variabel Good Corporate Governance 
(GCG) adalah sebesar 4.14. Hal ini menunjukkan bahwa prinsip-prinsip Good Corporate Governance ( $G C G$ ) merupakan salah satu faktor utama pendukung kemajuan perusahaan.

Kinerja Karyawan

Tabel 4

Rincian Jawaban Untuk Variabel Variabel Kinerja Karyawan

\begin{tabular}{|c|c|c|c|c|c|c|}
\hline \multirow{2}{*}{ Indikator } & STS & TS & N & S & SS & Rata - \\
\cline { 2 - 6 } & 1 & 2 & 3 & 4 & 5 & rata \\
\hline Y1.1 & - & 11 & 27 & 67 & 51 & 4.01 \\
\hline Y1.2 & 1 & 2 & 20 & 65 & 68 & 4.26 \\
\hline Y1.3 & - & - & 6 & 64 & 86 & 4.51 \\
\hline Y1.4 & 1 & 1 & 30 & 70 & 54 & 4.12 \\
\hline Jumlah & 2 & 14 & 83 & 266 & 259 & 4.23 \\
\hline
\end{tabular}

Dari Tabel 4 dapat dilihat bahwa rata-rata jawaban yang diberikan oleh para responden untuk masing-masing indikator variabel kinerja karyawan adalah sebesar 4.23. Secara umum hal ini menunjukkan bahwa kinerja karyawan di perusahaan/ subyek penelitian sudah cukup baik, namun tetap perlu diperbaiki terutama untuk beberapa variabel yang mempengaruhi seperti kepemimpinan transformasional, kompensasi dan prinsip-prinsip Good Corporate Governance (GCG).

\section{Uji Outer Model}

Convergent Validity

Gambar 3

Convergent Validity Awal

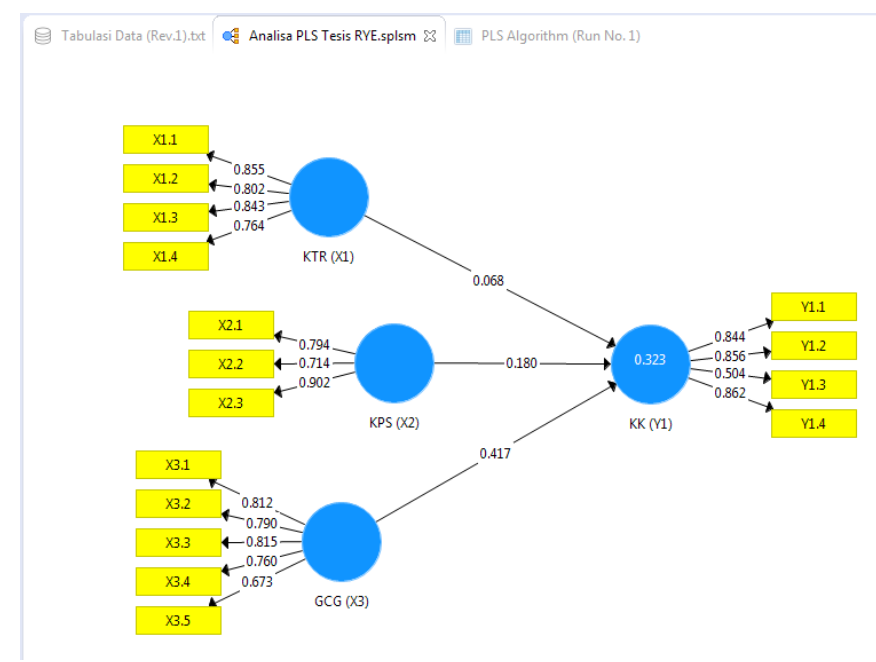


Tabel 5

Convergent Validity Awal

\begin{tabular}{|c|c|c|}
\hline Variabel & Indikator & Standar Loading Factor \\
\hline \multirow{2}{*}{ Kepemimpinan } & X1.1 & 0.855 \\
Transformasional & X1.2 & 0.802 \\
& X1.4 & 0.843 \\
& X2.1 & 0.764 \\
\hline Kompensasi & X2.2 & 0.794 \\
& X2.3 & 0.714 \\
Good Corporate & X3.1 & 0.902 \\
Governance & X3.2 & 0.812 \\
& X3.4 & 0.790 \\
& X3.5 & 0.815 \\
& Y1.1 & 0.760 \\
Kinerja Karyawan & Y1.2 & $\mathbf{0 . 6 7 3}$ \\
\hline \multirow{3}{*}{ Y1.3 } & Y1.4 & 0.844 \\
& & $\mathbf{0 . 5 0 4}$ \\
& & 0.862 \\
\hline
\end{tabular}

Merujuk pada Tabel 5 diatas menunjukkan bahwa terdapat dua indikator variabel yaitu X3.5 dan Y1.3 yang tidak memenuhi persyaratan sebagai reflector dari variabel laten dikarenakan memiliki nilai loading factor untuk masing-masing indikator tersebut bernilai $<0.70$, sehingga selanjutnya kedua indikator tersebut akan dihilangkan dalam penelitian ini dan akan dilakukan pengujian ulang. Hasil dari pengujian ulang tersebut adalah sebagai berikut:

Gambar 4

\section{Convergent Validity Akhir}

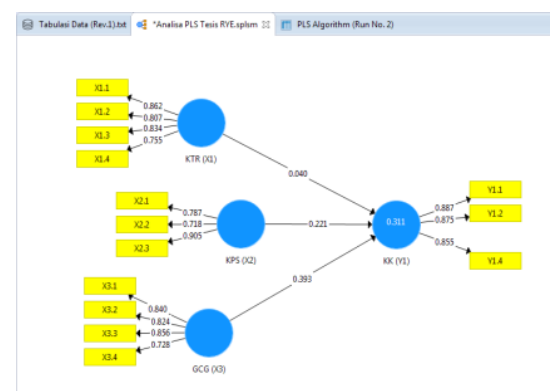


Tabel 6

Tabel Hasil Convergent Validity Akhir

\begin{tabular}{|c|c|c|}
\hline Variabel & Indikator & Standar Loading Factor \\
\hline \multirow{3}{*}{ Kepemimpinan } & X1.1 & 0.862 \\
Transformasional & X1.2 & 0.807 \\
& X1.4 & 0.834 \\
& X2.1 & 0.755 \\
\hline \multirow{2}{*}{ Kompensasi } & X2.2 & 0.787 \\
& X2.3 & 0.718 \\
Good Corporate & X3.2 & 0.905 \\
Governance & X3.3 & 0.840 \\
& X3.4 & 0.824 \\
& Y1.1 & 0.856 \\
& Y1.2 & 0.728 \\
\hline \multirow{2}{*}{ Kinerja Karyawan } & Y1.4 & 0.887 \\
& & 0.875 \\
& & 0.855 \\
\hline
\end{tabular}

Merujuk pada Tabel 6 diatas dapat disimpulkan bahwa keseluruhan indikator pernyataan telah valid dikarenakan nilai loading factor untuk masing-masing indikator tersebut bernilai $>0.70$, sehingga hal ini menyatakan bahwa syarat convergent validity penelitian telah terpenuhi.

Discriminant Validity

Tabel 7

Discriminant Validity

\begin{tabular}{|c|c|c|c|c|}
\hline Variabel & GCG (X3) & KK (Y1) & KPS (X2) & KTR (X1) \\
\hline GCG (X3) & 0.814 & & & \\
\hline KK (Y1) & 0.521 & 0.873 & & \\
\hline KPS (X2) & 0.449 & 0.431 & 0.807 & \\
\hline KTR (X1) & 0.440 & 0.288 & 0.341 & 0.815 \\
\hline
\end{tabular}




\section{Tabel 8}

Perbandingan Average Varianced Extracted (AVE) dengan Akar AVE

\begin{tabular}{|c|c|c|}
\hline Variabel & Akar AVE & AVE \\
\hline GCG (X3) & 0.814 & 0.662 \\
\hline KK (Y1) & 0.873 & 0.761 \\
\hline KPS (X2) & 0.807 & 0.651 \\
\hline KTR (X1) & 0.815 & 0.665 \\
\hline
\end{tabular}

Dari Tabel 7 dan 8 diatas menunjukkan bahwa masing-masing variabel memiliki nilai akar AVE lebih besar dari Average Varianced Extracted (AVE) dan nilai AVE itu sendiri $>0.50$, sehingga dapat disimpulkan bahwa syarat discriminant validity telah terpenuhi.

Composite Reliability

Tabel 9

Composite Reliability

\begin{tabular}{|c|c|}
\hline Variabel & $\begin{array}{c}\text { Composite } \\
\text { Reliability }\end{array}$ \\
\hline GCG (X3) & 0.886 \\
\hline KK (Y1) & 0.905 \\
\hline KPS (X2) & 0.847 \\
\hline KTR (X1) & 0.888 \\
\hline
\end{tabular}

Merujuk pada paparan hasil analisa pada Tabel 9 diatas, dapat dipahami bersama bahwa masing-masing variabel telah memenuhi persyaratan reliabilitas suatu variabel didalam penelitian dikarenakan masing-masing variabel memiliki nilai lebih dari 0.60 (Ghozali, 2014).

\section{Uji Inner Model dan Goodness of Fit}

\section{Tabel 10}

Hasil Uji Goodness of Fit

\begin{tabular}{|c|c|}
\hline Variabel & R Square \\
\hline Kinerja Karyawan (KK) & 0.311 \\
\hline
\end{tabular}


Berdasarkan Tabel 10 diatas menunjukkan bahwa variabel kinerja karyawan hanya mampu dipengaruhi sebesar $31.10 \%$ oleh variabel kepemimpinan transformasional, kompensasi dan Good Corporate Governance, sedangkan sisanya sebesar $68.90 \%$ adalah pengaruh dari variabel lain diluar model struktural yang tidak dibahas didalam penelitian ini.

\section{Pengujian Hipotesis}

Pengujian hipotesis dalam penelitian ini dilakukan dengan cara melihat serta membandingkan antara nilai t statistic dari pengujian inner model yang telah dihasilkan dengan standar nilai $\mathrm{t}$ dalam tabel nilai distribusi t. Apabila nilai t statistic yang dihasilkan $>1.96(\alpha=5 \%)$, maka hubungan antar variabel laten tersebut dapat dikatakan signifikan. Tiga hipotesis akan dicoba dijawab dan dijelaskan dalam penelitian ini, dan berikut dibawah ini adalah hasil dari pengujian hipotesis tersebut:

Tabel 11

\section{Rincian Pengujian Hipotesis}

\begin{tabular}{|c|c|c|c|}
\hline Hipotesis & Hubungan & T Statistik & Kesimpulan \\
\hline $\mathrm{H}_{1}$ & KTR --> KK & 0.332 & Tidak Signifikan \\
\hline $\mathrm{H}_{2}$ & KPS --> KK & 1.617 & Tidak Signifikan \\
\hline $\mathrm{H}_{3}$ & GCG --> KK & 3.041 & Signifikan \\
\hline
\end{tabular}

\section{Gambar 5}

Hasil Analisa Penelitian (Bootstrapping)

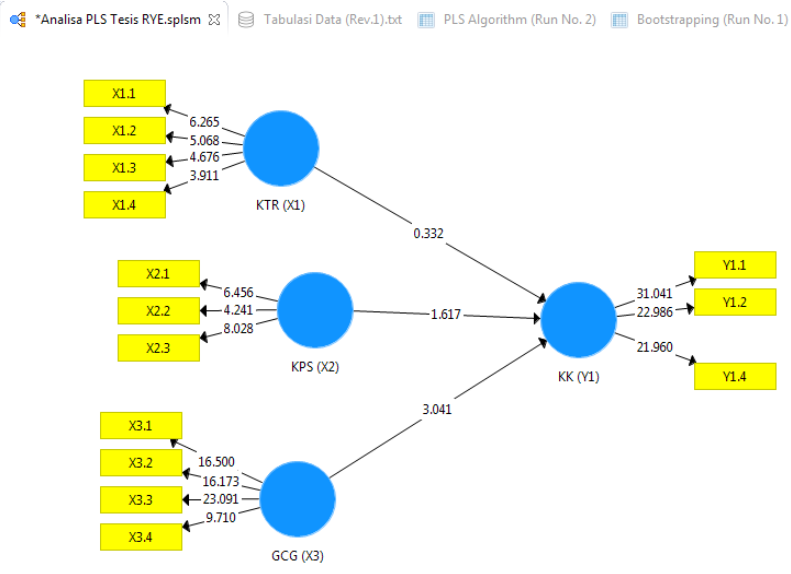

Berdasarkan Tabel 11 dan Gambar 5 diatas dapat disimpulkan bahwa hanya ada satu variabel yang berpengaruh signifikan terhadap kinerja karyawan, yaitu Good Corporate Govern ance $(G C G)$ dikarenakan nilai t statistik yang dihasilkan dari pengujian hipotesis bernilai lebih besar dari 1.96. Namun demikian keseluruhan variabel 
tersebut memiliki hubungan atau pengaruh positif terhadap kinerja karyawan dikarenakan hasil akhir pengujian bernilai positif.

\section{KESIMPULAN}

Kesimpulan dari penelitian ini sebagai berikut:

a. Kepemimpinan transformasional memiliki pengaruh positif terhadap kinerja karyawan sebesar 0.040, namun tidak memiliki hubungan yang signifikan, dikarenakan nilai t-statistik dari variabel ini adalah $<1.96(0.332)$.

b. Kompensasi memiliki pengaruh positif terhadap kinerja karyawan sebesar 0.221 , namun tidak memiliki hubungan yang signifikan, dikarenakan nilai t-statistik dari variabel ini adalah < $1.96(1.617)$.

c. Good Corporate Governance $(G C G)$ memiliki pengaruh positif terhadap kinerja karyawan sebesar 0.393 , serta memiliki hubungan yang signifikan, dikarenakan nilai t-statistik dari variabel ini adalah > 1.96 (3.041).

d. Ketiga variabel yang diteliti yaitu kepemimpinan transformasional, kompensasi dan Good Corporate Governance memberikan pengaruh Kinerja karyawan sebesar $31.10 \%$ ( $R$-square $=0,311)$, artinya $68.90 \%$ lainnya dipengaruhi oleh variabel-variabel lain yang dapat berpengaruh terhadap kinerja karyawan namun tidak diteliti dalam penelitian ini.

\section{REFERENSI}

Amri, Saiful, Haryono, Andi Tri., Warso, M Mukery. (2016),"Pengaruh Good Corporate Governance Terhadap Kinerja Karyawan PT. Aditec Cakrawiyasa Semarang”, Journal of Management, Vol.02 No.02 Maret 2016.

Bircan, Ismail, dan Gencler, Funda. (2015), "Analysis of Innovation-Based Human Resources for Sustainable Development", Procedia - Social and Behavioral Sciences, Vol.195, Hal.1348 - 1354.

Brandas, Claudiu. (2013), "Formal representation of Corporate Governance Principles and Codes", Procedia - Social and Behavioral Sciences, Vol.73, Hal. 744 - 750.

Cech, Martin, Yao, Wenlong, Samolejova, Andrea, Li, Jun., dan Wicher, Pavel. (2015), "Human Resources Management in Chinese manufacturing companies", Perspectives in Science, Vol.73, Hal.1 - 4.

Ciolacu, Mihai Valentin. (2012), "Human Resources Management In Revitalizing The Organization”, Romanian Journal Of Experimental Applied Psychology, Vol.3, Hal. $12-17$.

Dembo, Abubakar M., dan Rasaratnam, Syamarlah. (2014), "Corporate governance and disclosure in Nigeria: An empirical study", Procedia - Social and Behavioral Sciences, Vol.164, Hal.161 - 171.

Dessler, Gary. (2015), Human Resource Management, $14^{\text {th }}$ edition, Pearson Education Inc., Penerbit Salemba Empat, Jakarta.

Fahmi, Irham. (2016), Pengantar Manajemen Sumber Daya Manusia: Konsep \& Kinerja, $1^{\text {st }}$ edition, Mitra Wacana Media, Jakarta.

Febriani, Jayanti Ike., Al Musadieq, Mochammad, Afrianty, Tri Wulida. (2016), "Pengaruh Good Corporate Governance" Terhadap Kinerja (Studi Pada Karyawan PT. Pos Indonesia (Persero) Tuban)", Jurnal Administrasi Bisnis (JAB), Vol.32 No.1 Maret 2016, Hal.82 - 89.

Garcia-Guiu, Carlos, Moya, Miguel, Molero, Fernando, Moriano, Juan Antonio (2016), 
"Transformational Leadership and Group Potency in Small Military Units: The Mediating Role of Group Identification and Cohesion", Elsevier: Journal of Work and Organizational Psychology

Ghafoor, Azka, Qureshi, Tahir Masood., Khan, M. Aslam., Hijazi, Syed Tahir. (2011), "Transformational leadership, employee engagement and performance: Mediating effect of psychological ownership", African Journal of Business Management, Vol. 5 (17), Hal. 7391 - 7403.

Gibson, James L., Ivancevich, John M., Donnelly Jr., James H., dan Konopaske, Robert. (2006), Organizations: behavior structure processes, $12^{\text {th }}$ edition, McGrawHill/Irwin, The McGraw-Hill Companies Inc., United States

Ivancevich, John M., Konopaske, Robert., dan Matteson, Michael T. (2008), Perilaku dan Manajemen Organisasi, Jilid 1 Edisi Ketujuh, Erlangga, Jakarta

Kaihatu, Thomas S. (2006), "Good Corporate Governance dan Penerapannya di Indonesia", Jurnal Manajemen dan Kewirausahaan, Vol.8 No.1, Hal.1 - 9.

Komite Nasional Kebijakan Governance. (2006), Pedoman Umum Good Corporate Governance Indonesia, KNKG, Jakarta

Lendzion, Jaroslaw Piotr. (2015), "Human resources management in the system of organizational knowledge management", Procedia Manufacturing, Vol.3, Hal.674 - 680 .

Matei, Ani, dan Drumasu, Ciprian. (2015), "Corporate Governance and public sector entities", Procedia Economics and Finance, Vol.26, Hal.495 - 504.

Metwally, Ayman H., El-bishbishy, Nada.(2014), "The impact of transformational leadership style on employee satisfaction", The Business \& Management Review, Vol.5 No.3, Hal.32 - 42.

Mikhaylov, Feodor, Julia, Kolesnikova, dan Eldar, Salyakhov. (2014), "Current tendencies of the development of service of human resource management", Procedia - Social and Behavioral Sciences, Vol.150, Hal.330 - 335.

Neuman, W. Lawrence. (2015), Social Research Methods: Qualitative and Quantitative Approaches, $7^{\text {th }}$ edition, Edina T. Sofia, PT. Indeks, Jakarta.

Purwani, Tri. (2010), "Pengaruh Good Corporate Governance Terhadap Kinerja Perusahaan", Majalah Ilmiah Informatika, Vol. 1 No.2 Mei 2010, Hal 47 - 60.

Putri, I G A M Asri Dwija. (2015), "Sumber Daya Manusia, Good Corporate Governance, Dan Kinerja Perusahaan", PIRAMIDA Jurnal Kependudukan dan Pengembangan Sumber Daya Manusia, Vol.XI No.1 Juli 2015, Hal. 29 - 34.

Robbins, Stephen P.,dan Judge, Timothy A.(2015), Organizational Behavior, $16^{\text {th }}$ edition, Ratna Saraswati dan Febriella Sirait, Salemba Empat, Jakarta.

Sekaran, Uma, dan Bougie, Roger. (2009), Research Methods for Business: A Skill Building Approach, 5th edition, John Wiley \& Sons Ltd., TJ International Ltd., Cornwall.

Sugiyono, Prof. Dr. (2013), Metode Penelitian Manajemen, Setiyawami, SH., MPd, CV. Alfabeta, Bandung

Tofan, Mihaela, Bercu, Ana-Maria., dan Cigu, Elena. (2015), "Corporate governance framework in Romanian companies", Procedia Economics and Finance, Vol.20, Hal.629 - 636 .

Yildiz, Sebahattin, Basturk, Faruk, Boz, Ilknur Tastan. (2014), "The Effect of Leadership and Innovativeness on Business Performance", Procedia - Social and Behavioral Sciences, Vol.150, Hal.785 - 793 